\title{
From Wattie Creek to Wattie Creek: an oral historical approach to the Gurindji walk-off
}

\author{
Minoru Hokari
}

The Gurindji walk-off was a symbolic historic event in Australian race relations, particularly in terms of the Aboriginal land rights movement. The episode succeeded in gaining the wide public attention of contemporary Australia, it has been spoken of at length among the Gurindji people, and has also been discussed by academic historians. It remains an event that is deeply engraved on the memories of both Aboriginal and nonAboriginal people in Australia. Drawing upon field research with the Aboriginal people of Daguragu, ${ }^{1}$ this article attempts to interpret the meaning of the walk-off within Gurindji cultural practice and ideas of decolonisation, by using oral historical accounts of the Gurindji people.

There are many questions to investigate in order to understand the Gurindji's perspective of the walk-off event. l especially address three main questions. The first question relates to how the Gurindji people formulated the idea of the walk-off. Who invented or brought about the idea of the walk-off? This discussion will also examine the reason why the Wave Hill Aboriginal people, not other stations, were able to begin their struggle towards regaining their country. Secondly, I will examine the Gurindji people's action, which has most often been referred to as a 'strike' in the popular sense of the term. The question here is: to what extent was the Gurindji walk-off a strike? The third question is: why did they choose Wattie Creek and move there to establish the new community? In accordance with the above three questions, three sequences must be examined: (1) Before the walk-off, (2) the walk-off, and (3) the establishment of the Daguragu community.

To my knowledge, even though there were a number of studies and reports of the Gurindji walk-off episode, there have been no accounts exploring the questions I raised above in a comprehensive manner. Nor has there been extensive study of the Gurindji people's oral accounts of their history before the walk-off, or their retrospective views. My research seeks to redress this gap. Applying an oral historical approach with new questions, I will show the consistency of the Gurindji people's demand for regaining their country from the very beginning of this process. In the course of my analysis, I will show a Gurindji geography that is historically situated, that comes into being as a

1. Fieldwork was conducted by the author in January and June-December 1997, and JanuaryMarch 1999. 
dimension of colonial residence within an existing Dreaming landscape. However, before exploring oral accounts of the Gurindji people, I shall examine published and unpublished studies related to this event.

\section{I}

Among written accounts of the Gurindji walk-off, the first and most significant report is probably Frank Hardy's The Uniucky Australians. ${ }^{2}$ As a writer, Hardy was personally involved in this event and supported the Gurindji people. Encountering the Aboriginal struggle with white pastoralists, Hardy decided to help Aboriginal people in his own way: writing articles, seeking a way to raise funds for their survival during the 'strike', writing a petition to the Governor-General of Australia for the return of their land, and so on. His standpoint is clear: he actively assisted Aboriginal 'strikers', but did not initiate their movement. Even though there is no doubt that Hardy's commitment to the cause greatly encouraged the Gurindji elders' decision-making, his restraint in terms of respecting Aboriginal initiative is admirable. Hardy conscientiously resisted paternalism in his relationship with the Gurindji people. Therefore, my discussion does not intend to dismiss the extremely important role of Hardy as a supportive participant in the event. Nevertheless, I want to make it clear that Hardy's role was not to explore and interpret the background of the walk-off, but to immediately respond to the Gurindji people's request in an appropriate way. He played his role effectively, and thus, the Gurindji people respected him greatly. The Unlucky Australians is the product of his actual experience at that time.

However, when readers aspire to understand the Gurindji people's view of the walk-off, Hardy's book gives us a limited perspective. For instance, readers are not privy to the actual process involved in the development of the Gurindji's demands and decisions. Hardy simply presents the chronological order that he experienced. In The Unlucky Australians, the Gurindji people at first demanded (1) equal wages, then (2) social justice in every aspect, until finally they wanted (3) the return their land. If you read this book without further information, you would be most likely to accept that this was the chronological order in which the Gurindji people developed their ideas. However, it is crucial to emphasise that this was the order in which the Gurindji people told their story to Hardy, and this reflected what he and others were able to observe at the time.

Most of the research literature follows Hardy's order. This order often describes the Gurindji walk-off episode as moving 'from a strike to a land claim'. For instance, Stuart Macintyre says, 'What had begun as a strike had become a land claim'. ${ }^{3}$ Similarly, Lyn A Riddett titled her article 'The strike that became a land rights movement'. 4 However, my research has convinced me that the Gurindji walk-off was never principally a 'strike', but rather their main purpose was consistently 'to get their land back' from the very beginning. I explore this point as one of the keys to developing an understanding of what the walk-off means to the Gurindji people. Despite these problems, The Unlucky Australians contains a lot of oral accounts. In later discussion, I use Hardy's book as one of the primary contemporary sources.

\footnotetext{
2. Hardy 1968.

3. Macintyre 1985: 127.

4. Riddett 1997: 50.
} 
In other more academic studies, there are - broadly speaking - two different approaches towards the Gurindji walk-off: economic historical and socio-historical. Hannah Middleton was probably the first to explore the economic historical view. ${ }^{5}$ Gordon Briscoe also claims the importance of class analysis based on Marx's theory of the mode of production. ${ }^{6}$ Tina Jowett applies the theory of 'internal colonialism' to explain the process of exploitation of the Aboriginal workers at Wave Hill station. ${ }^{7}$ My previous work rejected theories such as 'internal colonialism' or 'articulation of mode of production' because these theories cannot adequately describe the active participation of the colonised Aboriginal economy. Instead, I have emphasised the Gurindji's struggle to maintain economic autonomy not only during, but also before the walk-off. ${ }^{8}$ These economic historical analyses are necessary for understanding the economic status of Aboriginal people living on stations and for explaining the economic aspects of their motivation for the walk-off. However, at the same time, economic considerations are just one of the many issues involved in understanding this event.

Socio-historical approaches emphasise racial conflict and its social complexity. Jack K Doolan's report clearly points out that the Aboriginal struggle was not for wages but for an equal relationship between two races. ${ }^{9}$ The land claim book written by Patrick McConvell and Rod Hargen shows good integration of both economic and sociological perspectives. ${ }^{10}$ The Aboriginal Land Commissioner's report on the Daguragu claim is also based on this land claim book. ${ }^{11}$ Using The Unlucky Australians, Ann McGrath emphasises 'white men's unfair sexual monopolisation of Aboriginal women' as one of the key reasons for the walk-off. ${ }^{12}$ Riddett reflects aspects of non-Aboriginal support, including her personal commitment. ${ }^{13}$ These socio-historical approaches certainly give us a wider view of the walk-off episode than the economic historical approach. However, we still do not know much about what the walk-off meant to the Gurindji people, a question to which I believe only an oral historical approach can provide an answer.

Jowett and Riddett used oral historical accounts from Daguragu, yet these were not presented as a major source in constructing the history of the walk-off, but were treated more as supplementary sources. ${ }^{14}$ McConvell and Hargen's work and a number of other reports were heavily based on the Gurindji people's oral accounts. ${ }^{15}$ The Aboriginal Land Commissioner's report especially dealt with the Gurindji people's oral testimonies to justify the Aboriginal ownership of the claimed area and its historical background. ${ }^{16}$ However, as I mentioned in the beginning, the questions I seek to

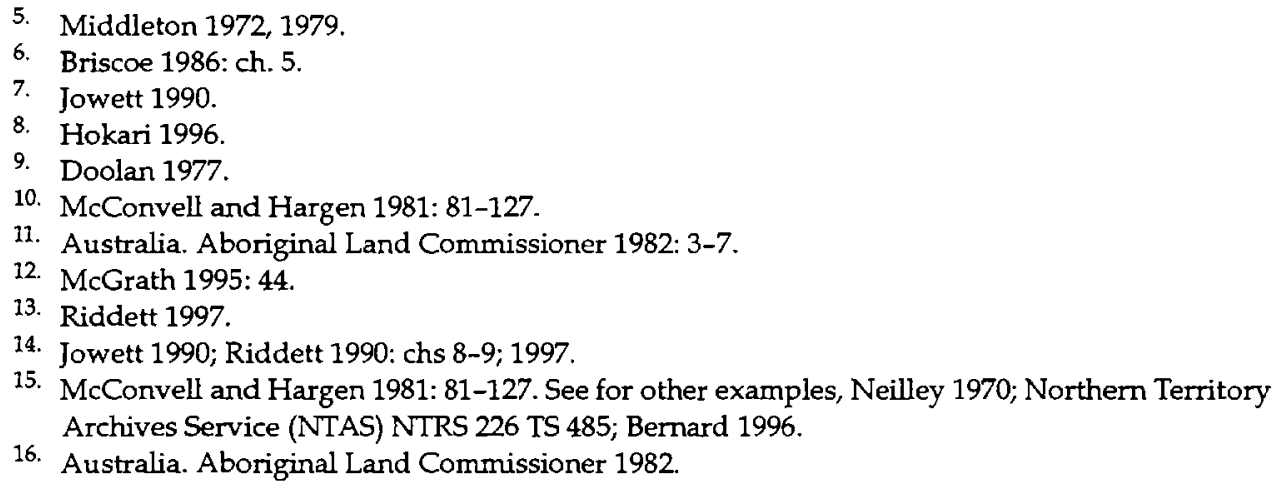


address - Who invented the idea of walk-off? Was the walk-off a strike in the European sense of the term? Why did those who participated choose Wattie Creek as their new community? - were not discussed at length in these previous oral historical works. Deborah B Rose's Hidden Histories includes a chapter on this 'strike' movement, in which she asserts that the Aboriginal people's primary demand was the return of their land. ${ }^{17}$ In 1982, Hobbles Danayarri, a Mudbura man of Yarralin, said to Rose, 'Tommy Vincent (Lingiari) told Lord Vestey: "You can keep your gold. We just want our land back"'. ${ }^{18}$ However, she primarily explored the perspective of Aboriginal people from Victoria River Downs rather than those from Wave Hill.

Thus, the purpose of this article becomes clear: it addresses the need to discuss the walk-off episode more thoroughly with specific questions based on the oral historical accounts of the Gurindji people. Only through this approach can we understand the meaning of the walk-off, not from an economic or sociological perspective, but more strongly from the Gurindji perspective.

\section{II}

A leader of the Wave Hill walk-off, Tommy Vincent Lingiari, a Gurindji elder, told Hardy what he had been thinking during the 'Vestey time', i.e. before the walk-off:

The manager of Wave Hill was Tom Pisher. Bestey man, Tom Pisher. ... Aboriginal men out in bush all time. White ringers come back to station ebry Friday night. That not right. I think to mesel' about that longa time. And think them Bestey mob don't treat Aborigine native people right way. ${ }^{19}$

A similar story is also told by Captain Major (Lupgna Giari), another Gurindji man who led the Aborigines of Newcastle Waters station and walked off to the vicinity of Elliott, about three months before the walk-off at Wave Hill station. Captain Major told Hardy:

I was thinkin' to mesel': I was reckon I only get ten dollar and all these other men only get six dollar. And them women might book a few things down at store, lucky if thirty bob left after two months. That not right. And I bin thinkin' agen: Wish we had someone behind us somewhere. ${ }^{20}$

Dexter Daniels, a young Aboriginal Roper River man who worked for the North Australian Workers Union, also remembers that Captain Major 'told me he had often thought this. He told me about having someone behind him, someone who would help the Aborigines'. ${ }^{21}$ These comments show us that both the Gurindji men, Vincent Lingiari and Captain Major had been thinking about the poor situation of their people. It was before Dexter Daniels and Hardy arrived to support Aboriginal stock workers that Lupgna Giari was looking for 'having someone behind him' who would help Aboriginal people.

I would like to explore this point: what did it really mean when Vincent Lingiari said, 'I think to mesel' about that longa time' and Lupgna Giari said, 'Wish we had

\footnotetext{
17. Rose 1991: ch. 24.

18. Rose 1991: 229.

19. Hardy 1968: 71.

20. Hardy 1968: 31 .

21. Hardy 1968: 28.
} 
someone behind us somewhere'? What was behind these statements? This should be the starting point for exploring our first question: where did the idea of the walk-off originate?

Most of the Aboriginal elders in Daguragu remember a Gurindji man, Sandy Moray Junganaiari, who seems to have been well known throughout the region. ${ }^{22}$ Frank Hardy met and wrote about him, describing Sandy as 'an ancient thin man'. ${ }^{23}$ Among the Aboriginal elders in Daguragu community, I held intensive discussions with Jimmy Mangayarri, Mick Rangiari, Peanut Pontiari and Stanly Sambo. They convinced me that Sandy Moray was the founder of the walk-off before Vincent Lingiari took the real action.

They told me that Sandy Moray was called 'Tipujurn' among the Gurindji and his country was Seal Gorge and Wattie Creek. ${ }^{24}$ During the mustering time, he did stock work on Wave Hill station, then he went back to his country, Seal Gorge, when the wet season (holiday time) started. ${ }^{25}$ Sandy Moray also worked for Alex Moray, a pastoral inspector for Vesteys, whom they called 'Vestey's big boss', or 'travelling boss' ${ }^{26}$ Tipujurn's European name, Sandy 'Moray' comes from Alex Moray. ${ }^{27}$ Since Sandy Moray worked for Alex Moray, 'he bin all over' Australia. ${ }^{28} \mathrm{His}$ frequent interstate trips gave Sandy Moray an unusual opportunity to observe the race relations at cattle stations in other places such as Queensland and Western Australia. In other states, especially in Queensland, Sandy Moray was impressed to see that Aboriginal workers and white Australians worked together and the conditions of the Aboriginal people were relatively better than in the Northern Territory. ${ }^{29}$ Sandy Moray wanted to show the better race relations in Queensland to his 'mate', Vincent Lingiari. One day (holiday time?) they went to the Northern Territory-Queensland border to meet some Queensland Aboriginal people. However, local police denied them entry because they did not have permission to travel into Queensland. ${ }^{30}$

Eventually, Sandy Moray started to think about changing the Aboriginal situation in his country: 'He (Sandy) bin start think'n, (and said) "I gonna get somebody. I got a bit of idea."'31 The Gurindji elders with whom I spoke could not fully explain to me

22. Rose 1991: 226. According to the 1962 census report, Sandy Moray was born in 1905 . See National Archives of Australia (NAA) E944/0 Wave Hill 4.

23. Hardy 1968: 161. Hardy also drew a portrait of Sandy Moray on the front page of The unlucky Australians.

24. Peanut Pontiari, Tape 31; Mick Rangiari, Tape 30.

25. Mick Rangiari, Tapes 30, 31; Peanut Pontiari, Tape 31. I also found his name in the Aboriginal employment records at Wave Hill station. For example, Sandy Moray had worked for 29 weeks in 1952, zero weeks in 1953, and 14 weeks up to July in 1954. He earned one pound a week, as did most of the other male Aboriginal workers. See, 'Employment of Aboriginals in the Pastoral Industry, Wave Hill Station', in NAA F1 52/736; NAA F1 53/674.

26. Jimmy Mangayarri, Tape 30; Mick Rangiari, Tape 31; Peanut Pontiari, Tape 31; Stanly Sambo, Tape 32. See also McGrath 1987: a photo page between 84 and 85; Cole 1988: 196.

27. Peanut Pontiari, Tape 31.

28. Jimmy Mangayarri, Tape 30; Mick Rangiari, Tape 31; Peanut Pontiari, Tape 31.

29. Mick Rangiari, Tape 31; Jimmy Mangayarri, Tape 30.

30. Jimmy Mangayarri, Tape 30; Mick Rangiari and Stanly Sambo, dictated, Daguragu, 22 Dec 1997, Fieldnote no. 4.

31. Mick Rangiari, Tape 31; Mick Rangiari, Tape 32. 
how Sandy Moray developed the idea of changing the situation of his own country. They did suggest that Tipujurn was good at following the white man's ideas and practices because he had known Alex Moray for a long time. ${ }^{32}$ They also told me that Sandy Moray may have met unionists in Queensland and learned how to fight. ${ }^{33}$ Mick Rangiari suggested that Sandy Moray had a good 'brain' so that 'maybe he bin think' $n$ himself. ${ }^{34} \mathrm{He}$ also said, 'He (Sandy) bin think'n every night. ${ }^{35}$

On the other hand, what they clearly remembered is that, one evening, Sandy Moray called a meeting under the 'partiki tree' (Terminalia arostrata, or 'nut tree') ${ }^{36}$ at Wattie Creek. Jimmy Mangayarri was one of the participants. Other participants he remembered were Vincent Lingiari, and Peanut Pontiari's father, Bob Warriyawun. ${ }^{37}$ Mick Rangiari was a little boy at that time. ${ }^{38}$ Pincher Nyurrmiyari (Manguari) was not there because he was not yet a member of this project. ${ }^{39}$ At this meeting, Sandy Moray told them, 'What's for we work'n langa kartiya [white people]? We wanna fight the kartiya. Get the country back! Don't worry about it. You gotta [will get] land, no worry. You gotta land, you gotta station, you gotta horse, you gotta buluki [bullock], you gotta motika [car]. ${ }^{40}$ Initially, most of them did not believe him. ${ }^{41}$ However, Sandy Moray patiently explained his idea to people. He said, 'We gonna do something' and explained his plan every night. ${ }^{42} \mathrm{He}$ talked 'all night, and get old men made' em understand' ${ }^{43}$ Jimmy Mangayarri and Mick Rangiari confirmed that these meetings had been held a long time before Hardy visited the Gurindji country. ${ }^{44}$

The ideas of returning their land and running the cattle station by themselves were formulated by Sandy Moray and had been in the Gurindji people's consciousness long before the actual walk-off occurred. Riley Young of Lingara told Rose that Sandy Moray also went to the Ngarinman country to explain his plan, which, according to Rose, appears to have been around 1950:

And old Sandy Moray used to come out from Wave Hill. ... Sandy Moray, Jangala [subsection] bloke. He used to come out there and tell us this story for us. Tell us. Ohhh, myall time. We were working for whiteman yet. He used to come out and tell us. He used to come out from Wave Hill for holiday, you know.

'Ah,' he told us, 'ah, you gotta change the law now. Eh? Might be four years' time, might be five years' time'. He (had had an) education for whiteman before. Working (for) the whiteman too long. He used to go down to Canberra, talk with them

32. Jimmy Mangayarri, Tape 30; Peanut Pontiari, Tape 31.

33. Stanly Sambo, Tape 32.

34. Mick Rangiari, Tape 30.

35. Mick Rangiari, Tape 31.

36. Wightman 1994: 50-1.

37. Jimmy Mangayarri, Tape 30. I personally think another walk-off leader, Captain Major, could have been there as well. Peanut told me that Bob Warriyawun passed away before the walkoff began (Peanut Pontiari, Tape 31).

38. Mick Rangiari, Tape 30.

39. Jimmy Mangayarri, Tape 30.

40. Jimmy Mangayarri, Tape 30.

41. Mick Rangiari, Tape 40.

42. Mick Rangiari, Tape 40.

43. Stanly Sambo, dictated, Daguragu, 22 Dec 1997, Fieldnote no. 4.

44. Jimmy Mangayarri, Tape 30; Mick Rangiari, Tape 31. 
Waterside Union. Talking with them. Telling them. Sneaking without no permit... . He used to come out telling us: 'We gotta get this land back. Don't tell anybody'. ${ }^{45}$ However, if Sandy Moray was the person who conceived the project, was there a reason that prevented him from leading the walk-off? Peanut Pontiari explained that he was already too old to become a leader of all the actions they would take. ${ }^{46}$ Instead, Sandy Moray said to Vincent Lingiari, 'You gotta do something ${ }^{47}$ and told people, 'You can do it. No body gonna stop you. ${ }^{48}$ Here, they were ready to take action. The only thing they had to do in advance was to look for someone from outside who could help the people to achieve the purpose. Supporter/s must know how to deal with white agencies such as Vesteys, the government and the Australian media.

This story of Sandy Moray holds the answer to the question I raised above. When Vincent Lingiari said, 'I think to mesel' about that longa time' and Captain Major said, 'Wish we had someone behind us somewhere', they meant that they had been thinking about how to put Tipujurn's plan into practice and were looking for someone to facilitate their project. Their project was, from the very beginning, to get their land back and to establish their own cattle station.

One may wonder why the story of Sandy Moray has been strangely neglected by the many previous oral accounts of the Gurindji people. We heard much about Vincent Lingiari as a leader of the walk-off, but rarely about Sandy Moray as a founder of it. As oral testimonies are often criticised, it is natural to cast doubt on the Gurindji people's memories of Sandy Moray. Was this aspect made up by the Gurindji people decades later? Is it likely that previous studies are more accurate than my research conducted 30 years after the events?

To answer this, I have already mentioned that there was little oral historical research which explored the specific question of 'who invented the walk-off?', instead of 'who led the walk-off?'. As shown above, Rose was one of the few people who collected a story of Sandy Moray. In addition, Patrick McConvell, who did intensive fieldwork at Daguragu in the mid-1970s, was also told that Sandy Moray formulated the idea of the walk-off. According to McConvell, he was referred to as 'Jangala' - his subsection name - since his name was taboo at that time. McConvell found out later 'Jangala' referred to Sandy Moray. ${ }^{49}$ Because of the nature of oral accounts, every detailed story of Sandy Moray may not be accurate, but it is compelling that the essence of the story has remained identical over the decades spanning the research done by McConvell, Rose and me.

It is also interesting to note that the story of Sandy Moray has been gradually revealed to the non-Gurindji; first, briefly, to McConvell in the 1970s, then to Rose in the 1980s, and to me, in more detail, in the late 1990s. I found that the Gurindji people today have become more comfortable telling the stories about the deeper background to the walk-off episode. I will return to this point after discussing the whole event.

\footnotetext{
45. Rose 1991: 226.

46. Peanut Pontiari, Tape 31.

47. Mick Rangiari, Tape 33.

48. Mick Rangiari, Tape 32.

49. Personal communication with Patrick McConvell, 14 August 2000.
} 
In order to look into the sequence before the walk-off in more detail and expand on our discussion above, it is also important to know about the Aboriginal relations and networks in different stations. I would especially like to explore the relations between the Gurindji elders of different stations.

It is interesting to note that Captain Major also worked for Alex Moray. In The Unlucky Australians, Captain Major told Hardy that 'I bin droving sometimes and I worked in Queensland. I worked for Alex Moray, Vestey man but very good' ${ }^{50}$ In addition, in 1977, he told McGrath that he used to work for Alex Moray. ${ }^{51}$ Jimmy Mangayarri also confirmed that Alex Moray used to take two 'boys', Captain Major and Sandy Moray. ${ }^{52}$ There is a strong possibility that the two Gurindji men from different stations, Captain Major from Newcastle Waters and Sandy Moray from Wave Hill, discussed what they had seen in Queensland and Western Australia and how to change the situation in their own country. They may also have visited or heard about the Pilbara (Findan) walk-off in 1946 in northern Western Australia. ${ }^{53}$

Eventually, Captain Major took the action first at Newcastle Waters and Sandy Moray told Vincent Lingiari to lead the walk-off at Wave Hill station. When reading The Unlucky Australians without knowledge of such background, readers probably believe Dexter Daniels was the one who chose Newcastle Waters as the first place to strike, and then Wave Hill station was chosen as the second strike through the discussion between Hardy and Dexter Daniels. ${ }^{54}$ However, Dexter Daniels had been to many stations to encourage Aboriginal workers to take action. In addition, conditions at Newcastle Waters were far better than at other stations in the area. ${ }^{55}$ Captain Major even said the manager of Newcastle Waters, Roy Edwards, was the 'best boss I ever work for. We had good house at Newcastle Water, cement floor and 'lectric light, good buildings. Better than other stations'. ${ }^{66}$ Nevertheless, the Aboriginal response to Dexter Daniels' offer was much swifter and more organised at Newcastle Waters than at many other stations. ${ }^{57}$ It is logical that if you are looking for help and waiting for the right moment, your response to the right offer will be quick.

It is also noteworthy that when Dexter Daniels met an old man called 'Double-O' from Newcastle Waters, he suggested that Daniels meet Captain Major. ${ }^{58}$ Why did Double-O tell him to see Captain Major? It is reasonable to assume that, through the net-

50. Hardy 1968: 30.

51. McGrath's interview with Captain Major, in A McGrath's Fieldnote 20 Jun 1977, Daguragu.

52 Jimmy Mangayarri, Tape 30.

53. Rowley (1971: 338 ) suggests that they may have had contact with the Pilbara people. On Pilbara walk-off, see, for example, Stuart 1959; Wilson 1979: 151-68; McLeod 1984; Hess 1994. Hess argues that it was'a tribal law meeting' that initiated the Pilbara strike (Hess 1994: 71). This view certainly corresponds to my argument about the Gurindji's initiative for the Wave Hill walk-off.

56. Hardy 1968: 30.

57. Dexter Daniels indicated to Hardy that he had been to many stations and 'they are ready to fight' (Hardy 1968: 24-6). Aboriginal people from Brunette Downs went on strike, but they soon went back to work (Hardy 1968: 27). As we know, successful actions, i.e. Newcastle Waters and Wave Hill, have been led only by the Gurindji men. 
work among Aboriginal people, they knew of the long awaited Gurindji project, and in particular that Captain Major (and Sandy Moray) were looking for 'someone behind them'. Before Captain Major received a letter from Dexter Daniels, he already 'bin hear about that young Dexter, an aboriginal who work for that Union mob in Darwin'. ${ }^{59}$ Here, you can see how the Aboriginal people were trying to make a 'connection' between people who were looking for assistance, and a person who was willing to help them. Hardy may have been unaware of, or have underestimated, the amount of planning among the Gurindji people before his involvement. In fact, Captain Major expresses this point of view in The Unlucky Australians:

Some white fella bin say Dexter tell me to strike because him higher man in tribe. That not right. Dexter Roper River man, me Gurindji; nothing to do with Roper River mob. We strike because we sick of small money. We had someone behind us. ${ }^{60}$

One may read this in a way to mean that Captain Major is asserting his authority over the Gurindji 'strikers'. But the oral historical approach gives us the deeper meaning of his statement: Dexter Daniels and Frank Hardy were the external conditions which simply ignited the Gurindji's long awaited project.

\section{III}

At this point, I would like to explore the sequence of the walk-off. It was on 23 August 1966 that Vincent Lingiari organised the Aboriginal people at Wave Hill station. ${ }^{61}$ They walked off the property for sixteen kilometres to the banks of the Victoria River near the Wave Hill Welfare Settlement. The main question here is: to what extent was the Gurindji walk-off a strike?

Why did they walk off? If the Gurindji's action was literally a 'strike', the aim of their action must have been equal wages or improvement of their living conditions. In

59. Hardy 1968: 31 .

60. Hardy 1968: 32.

61. It was in early August 1966 that Dexter Daniels met Vincent Lingiari in the Darwin hospital for the first time. Vincent Lingiari explained that he had been kicked by a donkey, which broke his foot. Hardy describes this meeting as if Dexter Daniels coincidentally knew Vincent Lingiari was at the Darwin Hospital so that he could visit this Gurindji leader of Wave Hill station in order to discuss the condition of the station (1968: 68-9, 72). It is probably true that, as Jowett writes, 'this discussion was the catalyst for fundamental change to Aboriginal political rights in Australia' (1990: 44). However, she does not explain (nor does Frank Hardy, or other studies) how this historic meeting was made possible. Was it too coincidental that while the strike had been going on at the Newcastle Waters station, a leader of the Wave Hill Aboriginal people broke his foot and went up to Darwin, and that Dexter Daniels happened to know he was in the hospital? There could well be something more behind this event.

Mick Rangiari told me another story about this meeting. Sandy Moray told Vincent Lingiari to pretend to be 'sick' (injured?) in order to go to Darwin to see Dexter Daniels (Mick Rangiari, Tape 33). We might believe that the story was made up later by the Gurindji people in order to control their own past more actively. However, his story may be true. As I discussed, if the Gurindji people were ready for the action and looking for someone behind them, and then found out what Captain Major did at Newcastle Waters station, it is reasonable that they wanted to hold discussions with Dexter Daniels about further action at Wave Hill station. Captain Major may have sent a message to Sandy Moray or Vincent Lingiari to come to Darwin to see Dexter Daniels. In the same manner, it would also not be surprising if Vincent Lingiari intentionally let a donkey kick his foot to create a reason to contact unionists in Darwin. 
that case, it would not be necessary to leave the station. They should have stayed there and simply stopped working in order to force the manager to negotiate.

An approach from the Gurindii's perspective gives us two main reasons why they wanted not only to stop working but also to leave the station. First, physically moving and shifting their living space is a traditional tactic for solving problems. Aboriginal people were, and in many aspects still are, nomadic. Mobility is one of their fundamental social modes of being. To move for economic reasons is a common practice in hunting-gathering Aboriginal societies. Mobility is also fundamental for maintaining their ceremonial exchange system. One cannot underestimate the importance of the physical and metaphysical functions of movement in Aboriginal social practice. ${ }^{62}$ Furthermore, the importance of Aboriginal mobility, even within the context of relatively settled contemporary lifestyles of Aboriginal communities, should not be underestimated. ${ }^{63}$ For the Gurindji people, the 'strike' did not mean negotiating with the Wave Hill manager. Instead, it meant leaving the station and shifting their living location. It is noteworthy that, from the beginning of their action, the Gurindji people did not want to stay at Wave Hill station. Changing their living space or 'camp' must have been the first step to independence from European authorities: be nomadic and white settlers cannot catch up with you!

This idea gives us the second reason: since their purpose was to regain the authority in their country, the first thing they had to do was to leave the European authority. For example, Pincher Nyurrmiyari says, 'We go back to Wave Hill if that Tom Pisher (the manager) leave, alla that Besty mob leave'.64 What they wanted was not an improvement of the condition at Wave Hill station, but to keep Vesteys out of their own country and run the cattle station. Vincent Lingiari explains more clearly why they did not stay at the station. He told Hardy that one Aboriginal person suggested they go back to Wave Hill:

He (an Aboriginal man) said: 'When white fella go on strike, they don't walk off straight away, they see their boss and talk things over. I worked for white man myself and start for sixpence maybe, or five bob, now I got proper money.' 'You work for that Welfare?' I (Vincent Lingiari) said. And he said: 'Yes, them Welfare blokes are all right. And Tom Pisher a good man. Why can't you fellas go back to work? And I said: 'I won't go back.' That's all I said. I never said no more. ${ }^{65}$

Vincent Lingiari implies that the Gurindji 'strike' was not like a white workers' strike. He did not want to negotiate with the manager; he wanted to leave the station. Peanut Pontiari remembers that Vincent Lingiari once asked people if they wanted to go back to the station, but they said, 'No, we don't wanna go back. No more station. One way walk-off, that's it! 66

The memorial day of 23 August 1966 was not the day the Gurindji people started negotiations with the white authorities, but the day they physically left foreign authority and returned to their own. In other words, the walk-off was not really an agitation

62. See, for example, Thomson 1949; Yengoyan 1968; Kolig 1984; Rose 1987.

63. See, for example, Young and Dooham 1989; Hokari 2000.

64. Hardy 1968: 111 .

65. Hardy 1968: 156 .

66. Peanut Pontiari, Tape 31. 
against Wave Hill station, but a spatial movement which allowed them to regain the power to establish their own community. They did not want to go back to Wave Hill unless Vesteys left the property. Higher wages and improved conditions may have been secondary considerations, but neither was the original or main purpose of their action.

Therefore, one needs to be careful when referring to the Gurindji walk-off as a 'strike'. I do not object to the usage of the expression 'Wave Hill strike', not only because it has already become part of the Australian lexicon but also because the Gurindji people also express their 'walk-off' as the 'strike'. However, the Gurindji people do not describe the sequence as moving 'from a strike to a land claim'. The word 'strike' should be understood in Gurindji Creole as meaning their physical walk-off from the European authority in order to fight for their land.

Later, Hardy himself admits that the issue was their land, not wages. $\mathrm{He}$ 'discovered that wages were not the only, perhaps not even the main, issue for the Gurindji men. They were concerned about their women, about the children getting an education, about housing, about dignity and self-respect, about tribal identity - and there hovered vaguely behind every thought a desire to live alone in their own land' ${ }^{67}$ As already discussed, it is remiss to read this change in Hardy's impression as a change in the Gurindji people's demands. Their aim was consistent, but their strategy was to avoid discussing their central project with white people in the beginning. They did not explicitly challenge the agenda or politics of unionists. Rather, they simply followed their own initiative in not returning from the walk-off, once outside support for their action had been secured.

However, if their aim from the outset was to regain their land, why did they not mention it to the outside supporters at the first stage? To answer this question, Rose provides us with the insight that for the Gurindji people, 'wages were a language which Europeans could understand, and constituted an issue which trade unions were known to support'. ${ }^{68}$ They were looking for allies who could help them to realise their plan, and finally found unionists such as Dexter Daniels, and a writer like Hardy, who were willing to help them. Gurindji people knew that unionists were keen on the issue of equal wages. They knew that 'equal wages' was the key term to gain the support from outsiders. After the walk-off leaders confirmed these people's support, the Gurindji people gradually started to educate them to understand the real purpose of their action.

This educational process can be observed in The Unlucky Australians in the supporters' confusion. From Hardy's point of view, he was the one who knew how to fight and that was why Dexter Daniels as well as the Gurindji people asked him to help. However, he eventually discovered the Gurindji's plan extended beyond his own conception. When the Gurindji leaders told Hardy about their desire to run their own cattle station, Anne Jeffrey, a wife of a welfare officer at Wave Hill, asked Hardy if this was originally Hardy's idea:

Anne asked: 'Did you have this in your mind when you came here, Frank? [...] 'Are you sure you didn't prompt them? If you did, they'll agree just to please you because you want to help them. Right?' 


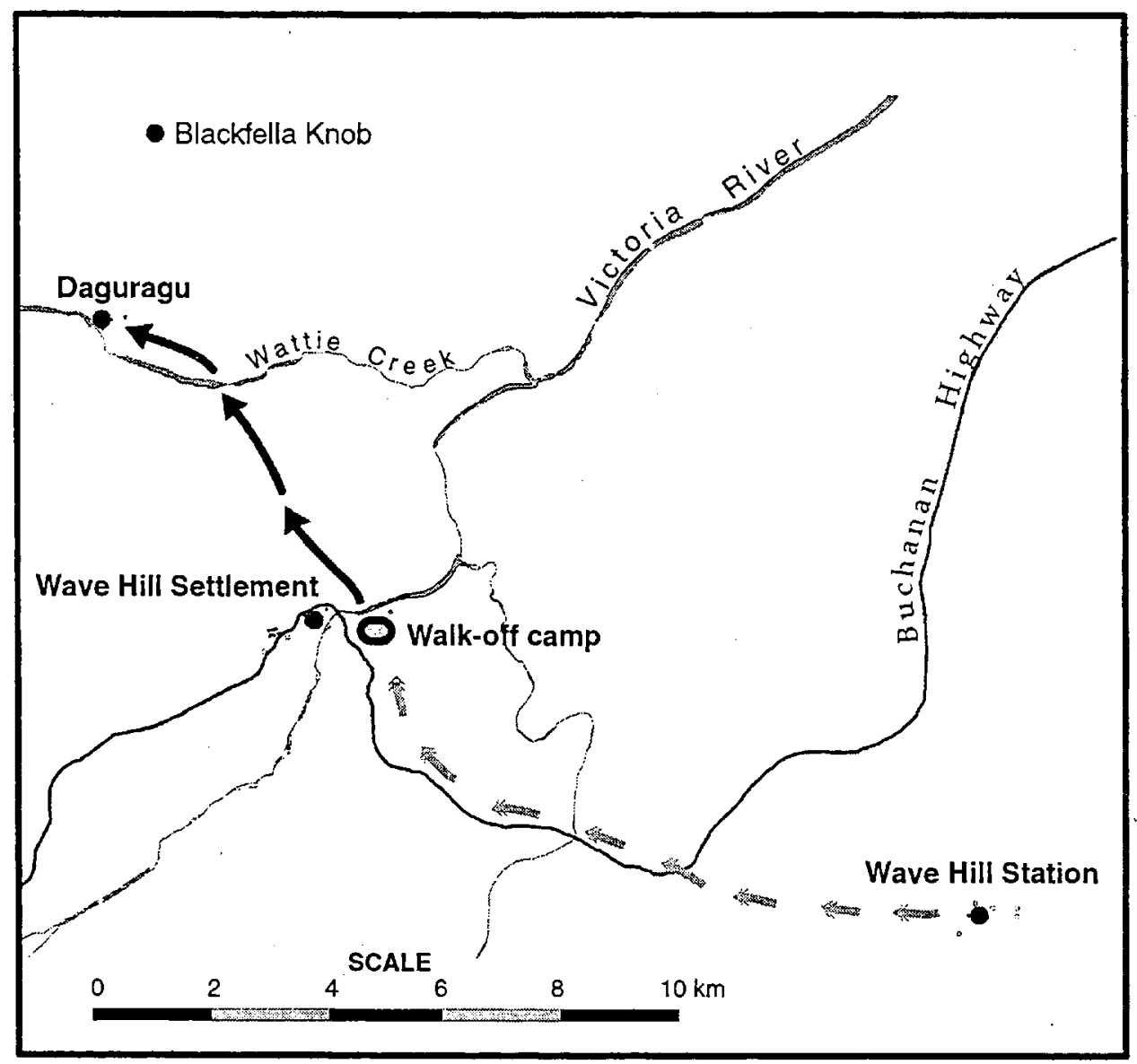

Figure 1 Movement of the Gurindji walk-off

(Frank said) 'No, Anne. Vincent mentioned it first on the way to Mount Sanford and I didn't take much notice. Then Pincher approached me. I'm positive I didn't plant it in their minds. It wasn't even in my mind. I was thinking of wages and conditions and strikes'. ${ }^{69}$

Later, when Hardy found their 'strike' seemed never-ending, he was confused about what the Gurindji people were really thinking regarding their future and wondered if he should tell them to stop the struggle and go back to Wave Hill. ${ }^{70}$ However, immediately after this, Vincent Lingiari told Hardy about their plan to move their camp to Wattie Creek and establish their own community. ${ }^{71}$ Through all these processes, we can see the Gurindji's initiative. At the same time, Hardy's constant support for their selfdetermination must also be acknowledged. It is of no doubt that his non-paternalistic attitude towards the Gurindji people facilitated the establishment of a firm rapport

\footnotetext{
69. Hardy 1968: 109-10.

70. Hardy 1968: 166.

71. Hardy 1968: 166-7.
} 
between Hardy and the Gurindji. Accordingly, Gurindji leaders gradually told the supporters about their plan and the final destination of their walk-off movement.

\section{IV}

In this section, I would like to discuss the sequence of the establishment of the Daguragu community at Wattie Creek. We will see how the Gurindji people finally accomplished their long awaited project. However, first I will look at the sequence of their movement near the Wave Hill settlement before going directly to Wattie Creek.

The most immediate need following the walk-off was maintaining access to an adequate food supply. Vincent Lingiari told people to look for bush tucker. ${ }^{72}$ They certainly counted on bush food, yet at the same time, a sedentary camp could not support over 200 people. Mick Rangiari often told me how they were relieved when a truck with plenty of food arrived in the walk-off camp. ${ }^{73}$ The Unlucky Australians also shows that it was urgent to keep enough food to feed the walk-off mob. ${ }^{74}$ When they left Wave Hill station, the nearest place they could get enough food from was Wave Hill Welfare Settlement. They also had to camp there because they definitely needed access to the white settlers' information network. It was essential to keep in touch with outside supporters, such as Daniels and Hardy. When they left the station, Wave Hill Welfare Settlement was the only place for them to access the telegram and other mailing systems, by which the Gurindji people could make a connection to the outside world. Furthermore, as we saw, their plan was flexible at the first stage. If Vesteys left their country, they could regain their authority over the country simply by going back to Wave Hill station and running the property by themselves. The Gurindji people needed to see how Vesteys as well as outside supporters reacted to their initial action. Therefore, the riverbank near the Welfare Settlement was ideally suited as a temporary camping place.

In March 1967, at the end of the wet season, seven months after their walk-off from Wave Hill station, the Gurindji people shifted their camp to Wattie Creek near the Seal Gorge Dreaming site. The main question here is: why did they choose Wattie Creek?

Most scholars simply explain that the Gurindji people chose Wattie Creek because it was a symbolically central place for them. For example, Jowett states that 'This area was chosen because it was the main place of the Gurindji Dreaming and the geographical centre of the traditional Gurindji country'. ${ }^{75}$ It is not surprising that people simply accept such an explanation because the Gurindji leaders themselves explained their decision to the public in the same way. In April 1967, with the assistance of Hardy and Bill Jeffrey, the Gurindji leaders wrote a petition to the Govemor-General for the return of five hundred square miles of their country. In this letter, they explain Wattie Creek is 'the main place of our dreaming. ${ }^{76}$

72. Hardy 1968: 74 .

73. Mick Rangiari, Tape 27; Mick Rangiari, Tapes 32, 33.

74. Hardy 1968: 74, 78-9.

75. Jowett 1990: 60. See, for other examples, Hardy 1968: 167; Forest 1985: 13; Australia. Department of Aboriginal Affairs 1986: 5. 
However, their explanation of Wattie Creek as a main place for their Dreaming was probably their tactic to make white people understand how important it was to establish their community there. Such a tactic is similar to the way they used 'equal wages' to gain public attention at the first stage. They needed a public reason that could help outside supporters understand their decision.

If you study the sacred sites in the Gurindji country, it is not difficult to find out that Seal Gorge/Wattie Creek is only one of many Dreaming sites for them. For example, McConvell and Hargen suggest there are over 200 sites in the Daguragu land claim area. ${ }^{77}$ TGH Strehlow explains that since the major totemic sites were 'linked according to the nature of their totems with the totemic sites of other subgroups and even of other tribes, not one of them was fitted in any sense to act as a sort of central 'capital' site for a whole tribal subgroup or a whole tribe' ${ }^{78}$ In Dreaming geography, there is no such 'centre' or 'main' place. Dreaming sites are connected to each other through the Dreaming tracks and you cannot claim one of them as a centre of these Dreamings. ${ }^{79}$ Certainly, Seal Gorge was one of the important Dreaming sites for the Gurindji people so there must have been no problem in shifting the camp there. However, in order to make settlers understand, they used a word like 'centre' or 'main' place to describe Wattie Creek.

However, we still do not have an answer as to why they chose Wattie Creek in particular and not some other Dreaming site. Jowett interviewed Mick Rangiari in 1990, and summarised his comments: 'it was Vincent Lingiari's decision to walk off Wave Hill station, but that was only after he had consulted with senior members of the community. When they were at Wave Hill settlement the elders decided to move to Wattie Creek ${ }^{80}$ There is no doubt that when it became clearer that Vesteys would never leave Wave Hill station, they were looking for a place near the Dreaming site for the location of their new community. From Wave Hill Welfare Settlement, one of the closest sites is Wattie Creek. This purely geographical factor may be one of the reasons for their decision

However, Wattie Creek has more meaning for the Gurindji elders and their walkoff project. It is important to note that even though the leader of the walk-off was Vincent Lingiari, he constantly 'consulted with senior members' about the decision and destination. One of the elders would have been Sandy Moray, an original planner of this movement and the one who told Vincent to take action. As I mentioned earlier, Wattie Creek was the country of Sandy Moray. Furthermore, as discussed earlier, the 'partiki tree meeting' during which Sandy Moray told his plan to the Gurindji elders for the first time was held at Wattie Creek as well. Jimmy Mangayarri took me to the big partiki tree where the meeting was held. The tree (Plate 1) was located in the middle of the Daguragu township, only about thirty metres away from the memorial stone of Gough Whitlam handing over the Gurindji land to Vincent Lingiari. The Daguragu community was established beside the memory of their historic meeting. Sandy Moray

76. Petition to the Governor-General, 19 April 1967, in McConvell and Hargen 1981: 109; Attwood and Markus 1999: 223-5.

77. McConvell and Hargen 1981: 58.

78. Strehlow 1970: 129.

79. Rose 1996:ch. 4; Hokari 2000.

80. Jowett 1990: 59. 


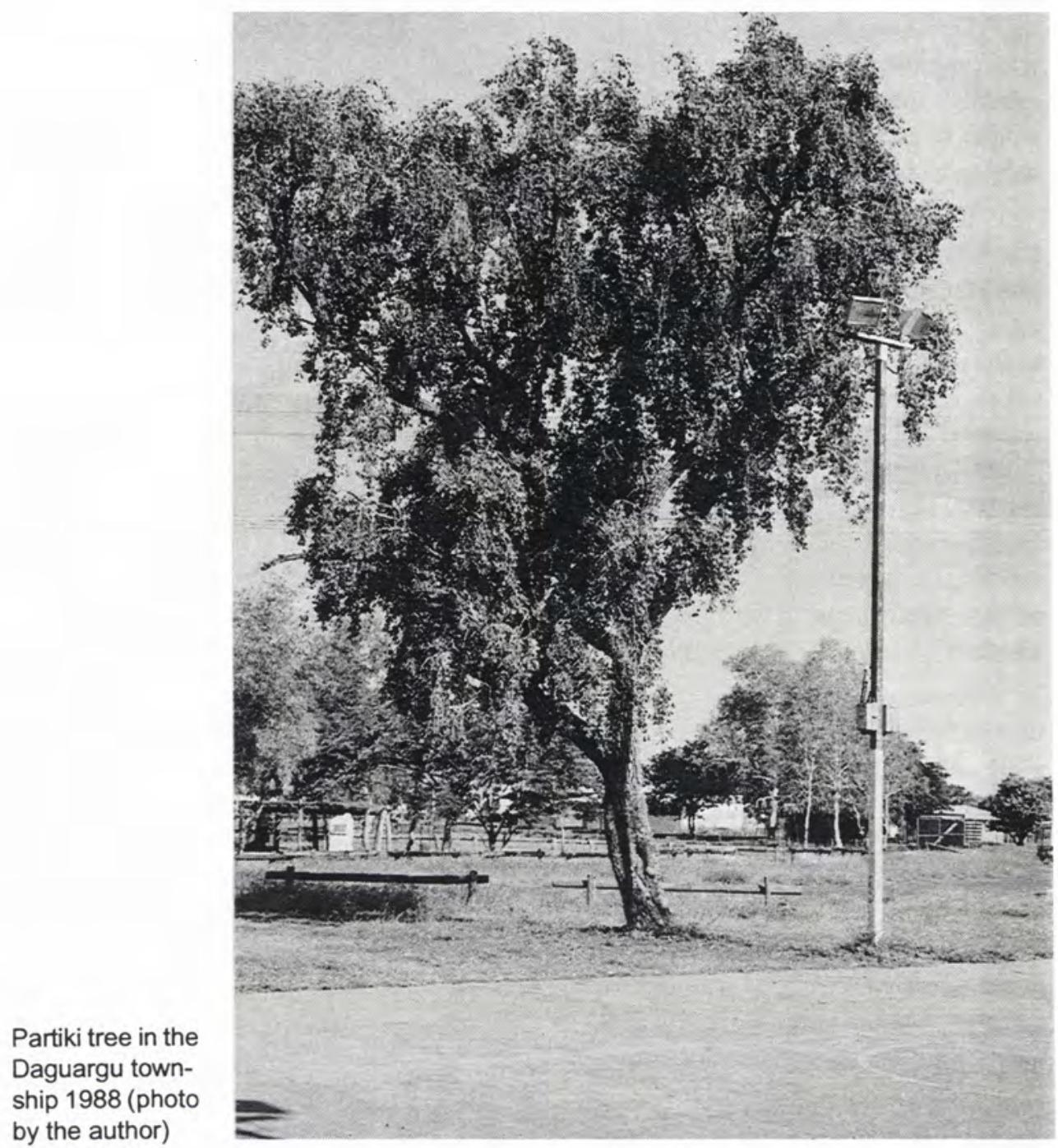

told people, 'Before I die, you gotta do it. ${ }^{.81}$ Mick Rangiari proudly said to me, 'So we did it!'82 The project of the walk-off had been formulated at Wattie Creek and returned to the same place at the end.

At this point, I want to return to an earlier question: why has the story of Sandy Moray rarely been told to the non-Gurindji? Why didn't the Gurindji people discuss Wattie Creek as the country of Sandy Moray in earlier research?

It is crucial to understand that the Gurindji people had been fighting for their land until 1986 when finally their inalienable freehold title was granted. Therefore, what they thought was worth telling to the non-Gurindji during that time was probably not 'who invented the walk-off?' or 'who belongs to Wattie Creek?'. Instead, their greater

81. Mick Rangiari, Tape 31.

82. Mick Rangiari, Tape 31. 
concern was letting outside supporters know about Vincent Lingiari as a leader of their movement and Wattie Creek as the country for all the Gurindji. It is indisputable that Vincent Lingiari was the leader of the Gurindji walk-off movement. It is also true that Daguragu became the symbolic place for all the Gurindji who fought for their land. These were the issues they wanted to communicate to non-Gurindji supporters at that time. Since then, the Gurindji people's political circumstances have changed and their rights over their country have become more certain. Today, the Gurindji people probably feel more comfortable telling the stories about different aspects of the walk-off episode. The story of Sandy Moray has been gradually revealed to the non-Gurindji according to their situations at different times.

Therefore, one should be more critical of the naive notion that the earlier oral testimonies are more accurate than the later. We should consider the historical and political situation in which any - oral and written - accounts are inevitably situated. Therefore, the assessment of the oral historical accounts should not only be based on their temporal distance from the events, but also according to their political context.

What was the Gurindji walk-off? Since I have discussed the sequence of the Gurindji walk-off episode, I shall now answer this question. From the very beginning, the Gurindji walk-off was not initiated by white people in order to protest against European authorities and gain better working conditions. Of course, there is no doubt that the Gurindji people needed and looked for supporters from outside. Without the presence of Dexter Daniels and Frank Hardy, the Gurindji project might not have happened. Without Australia-wide support, their project could not have been completed. Today, the Gurindji people remember Hardy and many other outside supporters as 'good kartiya [whites] helped ngumpin [Aboriginal people]'. The Gurindji people are deeply grateful to them for their devotion to the fight for the Gurindji country. However, let me repeat here that these were the external conditions that the Gurindji people had been long waiting for.

What was the Gurindji walk-off? The walk-off was the Gurindji mode of decolonisation of their land, planned and conducted by the Gurindji people and those related to the Gurindji country. Their aim was to physically leave European authority, to regain autonomy and sovereignty over their country, to establish their own community, and to run the cattle station by and for themselves. ${ }^{83}$

\section{Acknowledgements}

This article owes mostly to the Aboriginal people of Daguragu and Kalkaringi who kindly accepted me as a person learning their history. I would like to acknowledge their generosity and support of my study. My fieldwork was made possible largely through grants from the Research Fellowships of the Japan Society for the Promotion of Science for Young Scientists, the Research Management Committee of the University of New South Wales, and the Northern Territory History Awards. I gratefully acknowledge

83. Gurindji people still live in their community at Daguragu. However, their effort to run the cattle station failed after years of trials. The story of the time after the walk-off, or so-called 'New Generation', will be examined in my $\mathrm{PhD}$ thesis. 
helpful discussions with A McGrath and DB Rose who encouraged me to publish this article. Thanks are also due to Linda Bennett, Johanna Perheentupa, Philippa Webb, Rebecca Thomson and Carolyn Roberts for reading the manuscript and making a number of helpful suggestions.

\section{Tape recordings and fieldnotes}

Pontiari, Peanut. Tape 31, Interview with the author, Daguragu, 20 December 1997.

Major, Captain. Interview with Ann McGrath, Ann McGrath's Fieldnote, Daguragu, 20 June 1977.

Mangayarri, Jimmy. Tape 30, Interview with the author, Daguragu, 17 December 1997.

Rangiari, Mick. Tape 27, Interview with the author, Daguragu, 11 October 1997.

Rangiari, Mick. Tape 30, Interview with the author, Daguragu, 17 December 1997.

Rangiari, Mick. Tape 31, Interview with the author, Daguragu, 17 December 1997.

Rangiari, Mick. Tape 32, Interview with the author, Daguragu, 29 December 1997.

Rangiari, Mick. Tape 33, Interview with the author, Daguragu, 30 December 1997.

Rangiari, Mick. Tape 40, Interview with the author, Daguragu, 22 February 1999.

Rangiari, Mick and Stanly Sambo, Interview with the author, Fieldnote no. 4,

Daguragu, 22 December 1997.

Sambo, Stanly. Tape 32, Interview with the author, Daguragu, 22 December 1997.

Sambo, Stanly. Interview with the author, Fieldnote no. 4, Daguragu, 22 December 1997.

\section{Archival documents}

NAA E944/0 Wave Hill 4, [Census Report - Wave Hill 4].

NAA F1 52/736, Wave Hill Station, 1952-54.

NAA F1 53/674, Native Affairs Branch - Wave Hill Station - Maintenance of Government Dependants (Aboriginals) 1953-55.

NTAS NTRS 226 TS 485, Transcript of Interview with Mick Rangiari, The Gurindji

Walkoff, Conducted in October 1986 in Kalkaringi by Jack Doolan

\section{References}

Attwood, Bain and Andrew Markus, 1999. The struggle for Aboriginal rights. Sydney.

Australia. Aboriginal Land Commissioner, 1982. Gurindji land claim to Daguragu Station. Canberra.

Australia. Department of Aboriginal Affairs, 1986. Daguragu: an historical perspective of the Daguragu land claim. Canberra.

Bernard, Ida, 1996. An oral history from the Wave Hill strike. http:// jinx.sistm.unsw.edu.au/ greenlft/1996/251/251p15.htm.

Briscoe, Gordon, 1986. Aborigines and class in Australian history. BA (Hons) thesis, Australian National University, Canberra.

Cole, Tom, 1988. Hell west and crooked. Sydney.

Doolan, JKR, 1977. 'Walk-off (and later return) of various Aboriginal groups from cattle stations: Victoria River District, Northern Territory', in Berndt, RM (ed.) Aborigines and change: Australia in the '70s. Canberra, pp 106-13.

Forest, Peter, 1985. An outline of the history of Daguragu and locality, F.A.C.T.S. unpub- 


\section{lished paper.}

Hardy, Frank, 1968. The unlucky Australians. Melbourne.

Hess, M, 1994. 'Black and red: the Pilbara pastoral workers' strike, 1946.' Aboriginal History 18: 65-83.

Hokari, Minoru, 1996. 'Aboriginal economy and cattle labour: history of the Gurindji People.' (original in Japanese) Joumal of Australian Studies [Japan], 9: 14-28.

Hokari, Minoru, 2000. 'History happening in/between body and place: journey to the Aboriginal way of historical practice', in Habitus: A Sense of Place, Proceedings of the Habitus 2000 Conference, CD-ROM, Perth.

Jowett, Tina, 1990. Walking to Wattie Creek: the history of the strike by the Gurindji people and their struggle for land rights, 1966-1986. BA (Hons) thesis, University of New South Wales, Sydney.

Kolig, Erich, 1984. 'The mobility of Aboriginal religion', in Charlesworth, M. et al. (eds) Religion in Aboriginal Australia: an anthology, St Lucia, pp 391-416.

Macintyre, Stuart, 1985. Winners and losers: the pursuit of social justice in Australian history. Sydney.

McConvell, Patrick and Hargen, Rod, 1981. A traditional land claim by the Gurindji to Daguragu Station. Alice Springs.

McGrath, Ann, 1987. 'Born in the cattle': Aborigines in cattle country. Sydney.

McGrath, Ann, 1995. "'Modern Stone-Age Slavery": images of Aboriginal labour and sexuality', in McGrath, Ann and Kay Saunders with J Huggins (eds) Aboriginal workers, Sydney, pp 30-51.

McLeod, DW, 1984. How the West was lost: the Native question in the development of Western Australia. Port Hedland.

Middleton, Hannah, 1972. The land rights and civil rights campaign of the Gurindji at Wattie Creek: an Australian manifestation of the world-wide national liberation movement. $\mathrm{PhD}$ thesis, Humboldt University. .

Middleton, Hannah, 1979. 'Rebellion in the South Pacific: five case studies: Aboriginal resistance: the Gurindji at Wattie Creek', in Mamak, Alexander and Ali, Ahmed (eds) Race class and rebellion in the South Pacific. Sydney, pp 114-26.

Neilley, Warwick, 1970. An interview with Pincher Numiari. ABSCHOL and Save the Gurindji Campaign, Sydney.

Riddett, Lyn A, 1990. Kine, kin and country: the Victoria River District of the Northern Territory, 1911-1966. Darwin.

Riddett, Lyn A, 1997. 'The strike that became a land rights movement: a southern "dogooder" reflects on Wattie Creek 1966-74' Labour History 72: 50-65.

Rose, Deborah Bird, 1991. Hidden histories: black stories from Victoria River and Wave Hill Stations. Canberra.

Rose, Deborah Bird, 1996. Nourishing terrains: Australian Aboriginal views of landscape and wilderness. Canberra.

Rose, Frederick GG, 1987. The traditional mode of production of the Australian Aborigines. North Ryde.

Rowley, CD, 1971. The remote Aborigines. Canberra. 
Strehlow, TGH, 1970. 'Geography and the totemic landscape in central Australia: a functional study', in Berndt, RM (ed.) Australian Aboriginal anthropology: modern studies in the social anthropology of the Australian Aborigines. Nedlands, pp 92-140.

Stuart, Donald, 1959. Yandy. Melbourne.

Thomson, Donald Ferguson, 1949. Economic structure and the ceremonial exchange cycle in Arnhem Land. Melbourne.

Wightman, Glenn et al., 1994. Gurindji ethnobotany: Aboriginal plant use from Daguragu, northern Australia. Darwin.

Wilson, John, 1979. 'The Pilbara Aboriginal social movement: an outline of its background and significance', in Berndt, RM and Berndt, $\mathrm{CH}$ (eds) Aborigines of the west: their past and their present. Nedlands, pp 151-68.

Yengoyan, Aram A, 1968. 'Demographic and ecological influences on Aboriginal Australian marriage sections', in Lee, RB and DeVore, I (eds) Man the hunter. Chicago, pp 185-99.

Young, Elspeth and Kim Dooham, 1989. Mobility for survival: a process analysis of Aboriginal population movement in central Australia. Darwin. 